\title{
X. On the alteration which light produces on red sulphurated arsenic, known under the name of realgar. Read in the French Institute
}

\section{B.G. Sage}

To cite this article: B.G. Sage (1802) X. On the alteration which light produces on red sulphurated arsenic, known under the name of realgar. Read in the French Institute, Philosophical Magazine Series 1, 13:49, 42-43, DOI: 10.1080/14786440208676089

To link to this article: http://dx.doi.org/10.1080/14786440208676089

曲 Published online: 18 May 2009.

Submit your article to this journal $[\pi$

Џll Article views: 2

Q View related articles $\sqsubset$ 


\section{[ 42 ] $]$}

X. On tbe Alteration wbich Light produces on Red fulphurated Arfenic, known under tbe Name of Realgar. Read in the Frencb Infitute by B. G. SAGE, Diredtor of the Firft Scbool of Mines*.

$\mathbf{L}$

IGHT alters the red colours of oxides or metallic calces. Minium as well as red oxide of mercury, when expofed to the light, becomes black, though in clofe glafs jars.

One of the moft celebrated chemifts, Scheele, made known that muriate of filver loft its white colour by light even when under water. The fame philofopher, having decompofed the light by means of a prifm, found that muriate of filver, heretofore known under the name of luna cornea, was coloured

In 4 feconds, by - the violet ray;
In 25 feconds, by - the purple ray;
In 29 feconds, by - the blue ray;
In 37 feconds, by - the green ray;
In 5 minutes, by - the yellow ray;
In 12 minutes, by - the orange ray;
In 20 minutes, by - the red ray.

Native realgar, which is found in confiderable maffes among the volcanic productions of Japan, is of a brilliant purple red when it has been polifhed. Large maffes of it are found alfo in the tin mines in the province of Kianfu, five days joumey from Nankin. Le Camus had a piece of it which weighed twenty-eight pounds. The fame naturalift has fome worked realgar, in the centre of which there is a vein of calcareous fpar. The Chinefe and Indians employ it for making pagodas and vafes. Having put one of thefe pagodas into a glafs cafe, to which neither the fun nor external air had any accefs, I found, fome months after, that the pagoda had loft its brilliancy and its red colour, and was covered with an efflorefcence of an orange-yellow colour, which readily detached itfelf and fell on the ftand: having collected this efflorefcence, and fufed it in a crucible, it prefented sealgar.

I have made known that orpiment, or yellow ore of arfenic, the flakes of which are of a brilliant golden-yellow colour, aad femi-tranfparent, paffes to the ftate of realgar, or fulphurated red ore of arfenic, when fufed or fublimated. I have prefented to the Inftitute a piece of orpiment, a part of which I have made to pafs to the ftate of realgar by applying beneath it the flame of a taper by means of a blowpipe : for this putpofe, the flame muft not be too ftrong.

$$
\text { * From the fame. }
$$


Pott has made known that orpiment contains only a tenth of fulphur. As this fubftance paffes to the ftate of realgar merely by the action of heat, and afterwards repaffes to the ftate of orpiment by the contact of light, it is evident that thefe two fubftances, fo different in colour, are compofed of the fame elements. Having taken the realgar pagoda from the glafs cafe, I faw that a part of it, which had not been expofed to the immediate contact of the light, had retained its colour and brilliancy.

The realgar which is fublimated at the Solfaterra under the form of octaedral cryftals, known under the name of ruby of arfenic, efflorefces alfo by the light.

XI. Tbe Marquis of Worcefter's Scantlings of Inventions.

This little tract, firtt publimed in 1655 , being not eafy to be met with, we infert a copy of it at the requeft of a number of our readers, and we Hatter ourfelves it will be acceptable to all of them.]

\section{$A$ Century of the Names and Scantlings of Inventions by me already practifed.}

\section{Seals abundantly fignificant.}

SEVERAL forts of feals, fome thowing by fcrews, others by gages faftening or unfaftening all the marks at once; others by additional points and imaginary places, proportionable to ordinary efcocheons and feals at arms, each way palpably and punctually fetting down (yet private from all others but the owner, and by his affent) the day of the month, the day of the week, the month of the year, the year of our Lord, the names of the witneffes, and the individual place where any thing was fealed, though in ten thoufand feveral places, together with the very number of lines contained in a contract, whereby falfification may be difcovered, and manifeftly proved, being upon good grounds fufpected.

Upon any of thefe feals a man may keep accounts of receipts and difburfements from one farthing to an hundred millions, punctually thowing each pound, fhilling, penny, or farthing.

By thefe feals likewife any letter, through written but in Englin, may be read and underftood in eight feveral languages, and in Englifh itfelf to clean contrary and different fenfe, unknown to any but the correfpondent, and not to be read or underftood by him neither, if opened before it arrive unto him ; fo that neither threats, nor hopes of reward, can 